\title{
REVIEW
}

UDC 577.112:616

doi: https://doi.org/10.15407/ubj88.05.018

\section{THE ROLE OF THE TNF RECEPTORS AND APOPTOSIS INDUCING LIGANDS IN TUMOR GROWTH}

\author{
O. H. MINCHENKO', D. O. TSYMBAL I, D. O. MINCHENKO ${ }^{1,2}$, O. O. RATUSHNA \\ ${ }^{1}$ Palladin Institute of Biochemistry, National Academy of Sciences of Ukraine, Kyiv; \\ e-mail: ominchenko@yahoo.com; \\ ${ }^{2}$ Bohomolets National Medical University, Kyiv, Ukraine
}

Tumor necrosis factor (TNF) superfamily receptors and TNF apoptosis inducing ligands play an important role in the realization of TNF function and control tumor growth. The TNF-related pathways are controlled by endoplasmic reticulum stress signaling, which has a crucial role in the control of cell proliferation and tumor growth. Furthermore, the inhibition of IRE1 (inositol requiring enzyme-1), which is a central mediator of endoplasmic reticulum stress sand mainly responsible for cell proliferation and apoptosis, leads to suppression of tumor growth through specific changes in the expression of genes encoding transcription factors, tumor suppressors, angiogenesis and apoptosis related proteins, including TNF superfamily receptors and TNF apoptosis inducing ligands. Therefore, changes in the expression level of TNF-related genes encoding TNF superfamily receptors and apoptosis inducing ligands possibly reflect metabolic reprogramming of cancer cells upon inhibition of IRE1-mediated endoplasmic reticulum stress signaling and correlate with suppression of glioma cell proliferation.

Key words: TNF superfamily receptors, TRAIL, decoy receptors, IRE1 inhibition, glioma cells.

$\mathrm{T}$ umor necrosis factor alpha (TNFA) is a multifunctional pro-inflammatory cytokine that belongs to the tumor necrosis factor (TNF) superfamily. TNF is a highly pleiotropic cytokine with multiple activities other than its originally discovered role of tumor necrosis in rodents. TNF is now understood to play a contextual role in driving either tumor elimination or promotion $[1,2]$. It is now clear that TNF has many different functions in cancer biology. In addition to causing the death of cancer cells, TNF can activate cancer cell survival and proliferation pathways, trigger inflammatory cell infiltration of tumors and promote angiogenesis and tumor cell migration and invasion. These effects can be explained by the diverse cellular responses that TNF can initiate through distinct signal transduction pathways, opening the way for more selective targeting of TNF signalling in cancer therapy $[3,4]$. This cytokine is involved in the regulation of a wide spectrum of biological processes including cell proliferation, differentiation, apoptosis, lipid metabolism, and coagulation. It has been implicated in a variety of diseases, including autoimmune diseases, insulin resistance, and cancer $[2,5]$. TNFA is mainly secreted by macrophages and can induce cell death of certain tumor cell lines. Knockout studies in mice also suggested the neuroprotective function of this cytokine.

The tumor necrosis factor superfamily (TNFSF) contains about thirty structurally related receptors and about twenty protein ligands that bind to one or more of these receptors. TNFA can bind to, and thus functions through its receptors (members of tumor necrosis factor receptor superfamily: TNFRSF) TNFRSF1A/TNFR1 and TNFRSF1B/ TNFR2 as well as through Fas-related death receptors have been discovered and include death receptors (DR3, DR4, DR5, and DR6), also known as TNFRSF25, TNFRSF10A, TNFRSF10B, and TNFRSF21, correspondingly [3, 6-9].

Death receptors have an extracellular region containing varying numbers of cysteine-rich domains and an intracellular region that contains the death domain. The death receptors are activated in a ligand-dependent or independent manner and transduce apoptotic signals via their respective intracel- 
lular death domains. In addition to death receptors, several decoy molecules have also been identified and include decoy receptor 1 (DcR1), DcR2, DcR3, and DcR4, also known as TNFRSF10C/TRAILR3, TNFRSF10D/TRAILR4/TRUNDD, and TNFRSF11B or osteoprotegerin (OPG), correspondingly $[10,11]$. The inhibitory decoy receptors (DcR1 and DcR2) co-expressed with death receptor 4 and 5 on the same cell can block the transmission of the apoptotic signal.

Tumor necrosis factor-related apoptosis-inducing ligand (TRAIL) or Apo2 ligand (Apo2L) is a member of the TNF superfamily of cytokines that induces the process of cell death (apoptosis) upon binding to its death domain-containing transmembrane receptors, death receptors 4 and 5 [12,13]. TRAIL is a cytokine that is produced and secreted by most normal tissue cells. Importantly, TRAIL preferentially induces apoptosis in cancer cells while exhibiting little or no toxicity in normal cells. To date, research has focused on the mechanism of apoptosis induced by TRAIL and the processes involved in the development of TRAIL resistance. TRAILresistant tumors can be re-sensitized to TRAIL by a combination of TRAIL with chemotherapeutics or irradiation. Studies suggest that in many cancer cells only one of the two death-inducing TRAIL receptors is functional [14]. Schematic representation the role of TNFA superfamily receptors and TNF apoptosis inducing ligands (TRADD and TRAIL) in the regulation of apoptosis, cell survival and proliferation is shown in Fig. 1.

The extrinsic apoptosis pathway is activated when certain members of the tumor necrosis factor receptor superfamily are oligomerized by their cognate ligands that are members of the TNF superfamily. The apoptosis-inducing capacity of a member of the TNFRSF relies on the presence of a death domain in the intracellular portion of the receptor protein. Such receptors are also referred to as death receptors. Binding of a TNFSF ligand to a TNFRSF receptor that is expressed on the surface of a cell results in the formation of a receptor proximal protein complex. This protein complex is the platform for further signaling events within the cell [15]. In case of death receptors like TNF-related apoptosisinducing ligand receptor 1 (TNFRSF10A/DR4/ TRAILR1), TNFRSF10B (DR5/TRAILR2/KILLER), CD95 (Fas), or TNF receptor 1 (TNFR1), this complex is termed death-inducing signaling complex (DISC). The compositions of the various DISCs have been intensively studied in the last decade. For the CD95 and the TNFRSF10A/TNTRSF10B DISCs, it is now clear that the adaptor protein Fas-associated death domain protein (FADD) forms part of these complexes and is necessary for recruitment of the proapoptotic signaling molecules caspase- 8 and caspase-10 [15]. Recruitment of these proteases allows for their activation at the DISC and subsequent induction of apoptosis. The caspase- 8 homologous cellular FLICE-like inhibitory protein (cFLIP) can also be recruited to the DISC, which acts as an anti-apoptotic regulator by interfering with activation of caspases 8 and 10 at the DISC. Interestingly, treatment of TRAIL-resistant tumor cells with proteasome inhibitors renders these cells sensitive for TRAIL-induced apoptosis [15].

\section{Tumor necrosis factor receptors}

Several tumor necrosis factor receptors (TNFRSF1A/TNFR1 and TNFRSF1B/TNFR2) and Fas-related death receptors (TNFRSF) have been discovered and include DR3/TNFRSF25, DR4/TNFRSF10A, DR5/TNFRSF10B, and DR6/ TNFRSF21 $[8,14,16]$. These receptors contain an extracellular region containing varying numbers of cysteine-rich domains and an intracellular region that contains the death domain. The death receptors are activated in a ligand-dependent or independent manner and transduce apoptotic signals via their respective intracellular death domains. Recent evidence suggests that tumor suppressor protein p53 upregulates the expression of death receptors Fas and DR5, and thus, may mediate apoptosis in part via Fas and/or DR5.

The DR3, also known as TNFRSF25 and LARD (lymphocyte-associated receptor of death), is a lymphoid-specific death domain containing receptor regulated by alternative pre-mRNA splicing [17]. Recently, it was shown that bee venom inhibits cervical tumor growth through enhancement of death receptor expressions and inactivation of nuclear factor kappa B (NF- $\kappa$ B) in mice [18]. Similar inhibitory effects of bee venom on cancer growth in primary human cervical cancer cells were also found. This inhibition of cancer cell growth was mediated by the induction of apoptotic cell death in a dose dependent manner [18]. Agreed with cancer cell growth inhibition, the expression of FAS, DR3 and DR6 as well as death receptor downstream pro-apoptotic proteins including caspase- 3 and BAX were concomitantly increased, but the NF- $\kappa \mathrm{B}$ activity and the expres- 


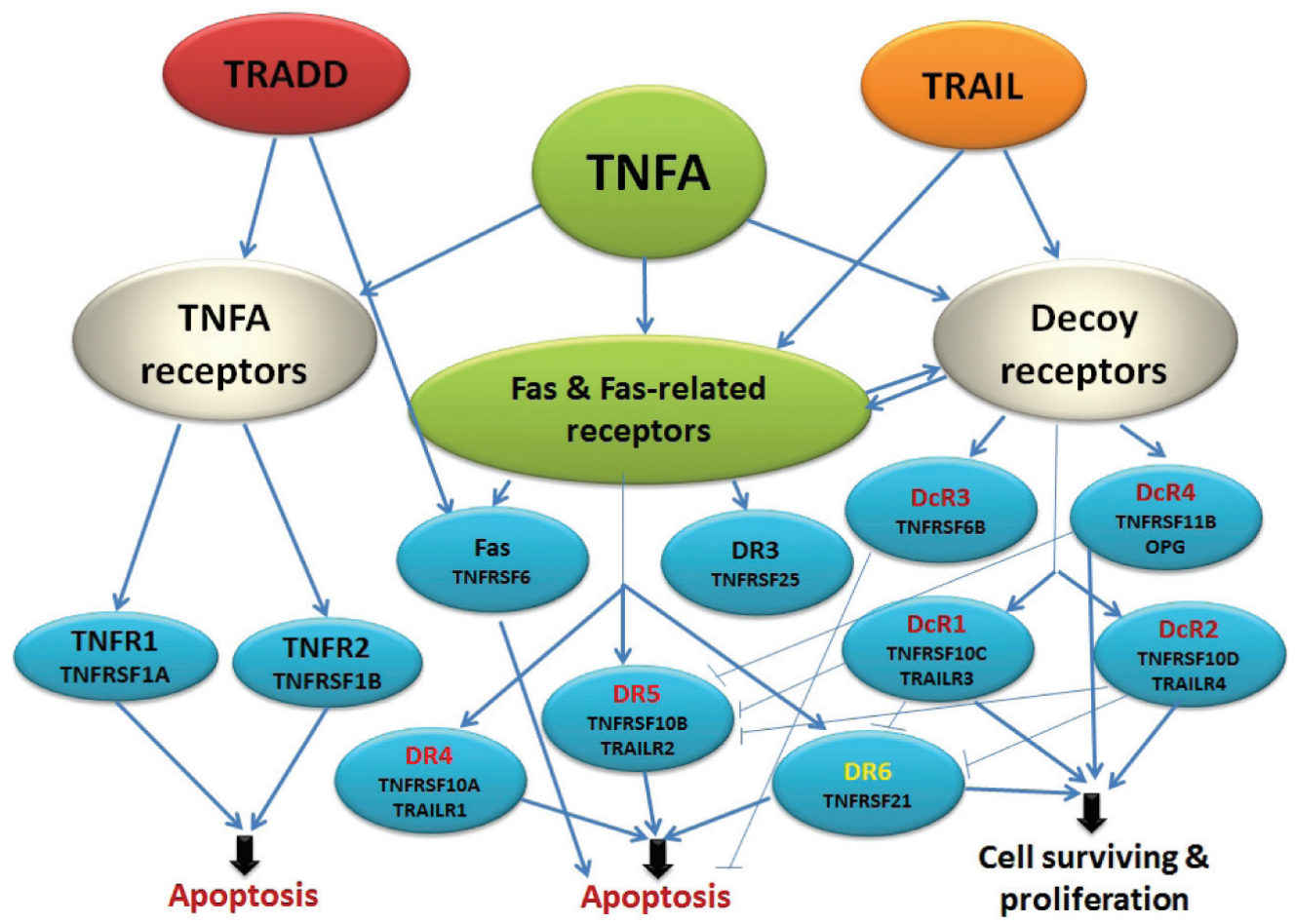

Fig. 1. Schematic representation of the role of tumor necrosis factor alpha (TNFA) superfamily receptors (TNFRSF) and TNF apoptosis inducing ligands (TRADD and TRAIL) in the regulation of apoptosis, cell survival and proliferation

sion of BCL-2 were inhibited by treatment with bee venom in tumor mice, human cancer cells and human tumor samples as well as cultured cancer cells. In addition, deletion of FAS, DR3 and DR6 by small interfering RNA significantly reversed bee venominduced cell growth inhibitory effects as well as NF$\mathrm{kB}$ inactivation [18].

The DR4/TNFRSF10Aand DR5/TNFRSF10B, also known as TRAIL-receptors 1 and 2, have proapoptotic properties, and pro-apoptotic receptor agonists targeting these death receptors hold promise for cancer therapy based on their selective ability to kill malignant versus healthy cells [19]. It was shown that TRAIL induces tumor-selective cell death by engaging the pro-apoptotic death receptors DR4 and DR5 in a wide variety of tumor cells while sparing vital normal cells $[20,21]$. The antitumor potential of the TRAIL pathway has been targeted by several therapeutic approaches including recombinant TRAIL and TRAIL-receptor agonist antibodies among others. Interest in sensitizing tumor cells to TRAIL-mediated apoptosis has driven investigations of TRAIL-receptor gene regulation, though regulation of the TRAIL gene has been less studied. Furthermore, TRAIL serves as a pro-apoptotic ef- fector molecule in the immune surveillance of cancer that is conditionally expressed by immune cells upon stimulation via an interferon-response element that was identified in early studies of the TRAIL gene promoter. The regulation of TRAIL gene expression involves several modalities of gene regulation including transcription factors, epigenetics, singlenucleotide polymorphisms and functionally distinct isoforms [20]. There is data that toll-like receptor 3 (TLR3) induces cell death via death receptors and mitochondria by up-regulating the transactivation of p63 isoform alpha (TAP63alpha), which is a crucial regulator downstream of TLR3 [22].

The activation of cell-surface death receptors represents an attractive therapeutic strategy to promote apoptosis of tumor cells. For this aim several recombinant human Apo2L/TRAIL and monoclonal agonist antibodies directed against death receptors -4 or -5 have been investigated [23]. Recently, it was shown that agonistic TNF-related apoptosisinducing ligand receptor-specific human monoclonal antibodies (TR1-IgMs) are attractive antitumor therapeutics [24]. These antibodies dramatically inhibited tumor growth in a xenograft model through the caspase activation cascade and in human tumor 
cell lines bound to TRAILR1, activated the caspase signal, and induced strong apoptosis (100-fold higher compared with the IgG form which did not demonstrate ideal apoptosis-inducing capacity in the absence of additional antibodies) [24]. It is interesting to note that cancer cells acquire TRAILresistance and thus avoid TRAIL-induced apoptosis and that PTBP1/HNRNP1 (Polypyrimidine Tract Binding Protein 1/Heterogeneous Nuclear Ribonucleoprotein Polypeptide 1), a splicer protein that is associated with pre-mRNAs in the nucleus and appears to influence pre-mRNA processing and other aspects of mRNA metabolism and transport and plays an important role in energy metabolism, is highly expressed in TRAIL-resistant human colon cancer DLD-1 [25]. Moreover, silencing PTBP1 by using siRNA for PTBP1 (siR-PTBP1) resulted in a significant increase in TRAIL-sensitivity along with the switching of pyruvate kinase muscle (PKM) isoforms from PKM2 to PKM1, leading to impaired Warburg effect, because the intracellular ATP levels were significantly increased and the production of lactate decreased. Notably, siR-PTBP1 canceled the resistance by increasing the expression level of TNFRSF10B/DR5 and effectively inducing the translocation of DR5 to the cell surface membrane. Also, siR-PTBP1 up-regulated the expression level of cysteine-rich angiogenic inducer 61 (CYR61; CCN1), which contributed to the enhanced sensitivity to TRAIL-induced apoptosis [25].

Nogueira et al. [26] have shown that TNFRSF10B/DR5 interacts with the core microprocessor components Drosha and DGCR8, thus impairing processing of primary let-7 miRNA in pancreatic cancer cells and opened new horizons of miRNA regulation. It has been shown that Xenografting TNFRSF10B silenced pancreatic cancer cells in SCID-mice indicated that there was notable suppression of tumor growth [26]. Recently, it was shown that the TRAIL pathway is selectively activated by small molecule ONC201/TIC10 in tumor cells [27]. The anti-tumor activity of ONC201 has been demonstrated in several preclinical models of cancer, including refractory solid tumors, a transgenic lymphoma mouse modeland pediatric non-Hodgkin's lymphoma (NHL) cell lines. ONC201 caused a dosedependent reduction in the cell viability of NHL cell lines that resulted from induction of apoptosis [27]. An induction of TRAIL and its receptor TRAILR2/ DR5 was also observed in these cell lines. Furthermore, dual induction of TRAIL and TNFRSF10B/
DR5 appeared to drive the observed apoptosis in these lymphoma cells.

Recently, Li et al. [28] have shown that TNFRSF10B/DR5 participate in the apoptosis of Hep G2 cancer cells, which are significantly enhanced by the combination of cisplatin with chrysin, a natural flavonoid widely found in various plants and foods and demonstrated effective anti-cancer activity. Cisplatin in combination with chrysin increased the phosphorylation and accumulation of $\mathrm{p} 53$ through activating ERK1/2 in Hep G2 cells, which led to the overexpression of the pro-apoptotic proteins TNFRSF10B/ DR5 and Bax and the inhibition of the anti-apoptotic protein $\mathrm{Bcl}-2$ [28]. In addition, combination of cisplatin and chrysin promoted both extrinsic apoptosis by activating caspase- 8 and intrinsic apoptosis by increasing the release of cytochrome $\mathrm{c}$ and activating caspase-9 in Hep G2 cells and other human cancer cells that are resistant to cisplatin [28]. It was also shown that (E)-2,4-bis(p-hydroxyphenyl)2-butenal (a MRP) induces apoptosis in human non-small-cell lung cancer (NSCLC) cells by p38 MAPK-mediated suppression of NF- $\mathrm{KB}$ and activation of TNFRSF10B/DR5, TNFRSF25/DR3, and TNFRSF21/DR6, which then activates the caspase-3 and caspase-9 pathways [29]. Inhibitory effect of (E)2,4-bis(p-hydroxyphenyl)-2-butenal on the growth of NSCLC cells due to induction of apoptosis was concentration- and time-dependent. Concomitantly, it significantly increased the expression of apoptotic proteins such as cleaved Bax and p53, but downregulated the expression of anti-apoptotic proteins Bcl-2, the inhibitor of apoptosis protein-1 and -2 . Of the death receptors activated, only TNFRSF10B knock down with siRNA reversed the effect of (E)2,4-bis(p-hydroxyphenyl)-2-butenal. Moreover, only pretreatment with a 338 MAPK inhibitor reversed (E)-2,4-bis(p-hydroxyphenyl)-2-butenal-induced cell growth inhibition, increase in cleaved caspase-3, -9 and TNFRSF10B expression, and NF- $\mathrm{KB}$ inactivation [29].

To achieve optimal clustering of TNFRSF10B/ DR5, a novel multivalent nanobody approach was taken with the goal of generating a significantly more potent DR5 agonist [30]. Thus, trivalent DR5 targeting nanobodies mimic the activity of natural ligand, and furthermore, increasing the valency of domains to tetramer and pentamer, markedly increased potency of cell killing on tumor cells, with pentamers being more potent than tetramers in vitro. The increased potency was attributed to faster kinetics of 
death-inducing signaling complex assembly and caspase- 8 and caspase-3 activation. Moreover, in vivo, multivalent nanobody molecules elicited superior anti-tumor activity compared to a conventional DR5 agonist antibody, including the ability to induce tumor regression in an insensitive patient-derived primary pancreatic tumor model [30]. Therefore, many agonistic monoclonal antibodies specific for TRAIL receptors induce apoptosis in multiple tumor cell types, but some TRAIL receptor-expressing tumor cells, including Jurkat T cells, are resistant to TRAIL receptor-specific monoclonal antibody-induced apoptosis. Kobayashi et al. [31] constructed a chimeric antigen receptor (CAR) of a TRAIL-receptor 1-specific single chain variable fragment (scFv) antibody (TRAIL-receptor 1-scFv-CAR), which killed Jurkat T cells via TRAIL-receptor 1-mediated apoptosis.

Recently, it was shown that methyl jasmonate, a botanical hormone that serves as a signal transduction intermediate and regulates cell death in stressed plants, induces cell cycle arrest, apoptosis and nonapoptotic cell death selectively in cancer cells [32]. The molecular mechanism through which methyl jasmonate induces apoptosis in human non-small cell lung cancer (NSCLC) was studied. It was found that methyl jasmonate triggered apoptosis via the DDIT3/ GADD153-TNFRSF10B/DR5-CASP axis. Thus, methyl jasmonate treatment significantly decreased the expression of CFLAR (CASP8 and FADD-like apoptosis regulator, an inhibitor of CASP8) in NSCLC cells, and ectopic expression of CFLAR partly protected cells from methyl jasmonate-induced apoptosis [32]. The activity of pro-apoptotic genes expression such as TNFRSF10BDR5 or TP63 is also regulated by the LTR 12 from endogenous retrovirus $9[33,34]$. When treating testicular cancer cells with HDAC inhibitors as well as the death ligand TNF-related apoptosis-inducing ligand (TRAIL), rapid cell death was observed, this depended on TNFRSF10B expression [34]. The promoter activity of LTR12 is largely confined to the testes, silenced in testicular carcinoma, but reactivated in testicular cancer cells by broad-range histone deacetylase (HDAC) inhibitors, which also induce LTR12 activity in cells derived from many additional tumor species [33]. Moreover, HDAC inhibitors also cooperate with cisplatin to promote apoptosis in testicular cancer cells. ERV9-LTRs not only drive a large set of human transcripts, but a subset of them acts in a proapoptotic manner [34].

The TRAIL is a potent and specific inducer of apoptosis in cancer cells, but not all pancreatic cancer cells respond to this apoptosis inducing ligand. To overcome resistance and improve the effectiveness of TRAIL-based therapies the constructs were created expressing soluble TRAIL variants that were rendered specific for either TRAILR1/ DR4 or TRAILR2/DR5 by amino acid changes in the TRAIL ectodomain. It was shown that the TRAILR1/DR4 specific variant had higher apoptosis-inducing activity in human pancreatic carcinoma Colo357 cells as well as PancTu1 cells that were additionally sensitized by targeting of X-linked inhibitor of apoptosis protein (XIAP), also known as inhibitor of apoptosis protein 3 (IAP3) [35]. Furthermore, the TRAILR1 specific recombinant protein (DR4) was more efficacious than recombinant wild type TRAIL on Colo357 xenografts in nude mice. Thus, synthetic biological approaches can potentially enhance the therapeutic efficacy of TRAIL-based therapies in pancreatic cancer, suggesting that they can possibly become part of individualized and tumor specific combination treatments in the future [35]. Most glioma cells are also resistant to TRAIL-induced apoptosis and this resistance to TRAIL limits its potential use as a drug for therapy of glioma. Khan et al. [36] have shown that evodiamine, a major bioactive compound of the Chinese herb Evodiae fructus, sensitizes U87 glioblastoma cells to TRAIL and inhibit cell growth in a dose-dependent manner; however, TRAIL alone failed to exert any cytotoxic effect. Combining TRAIL with evodiamine significantly increased the apoptotic rate of U87 glioblastoma cells, as compared to evodiamine treatment alone through increased expression of death receptors DR4 and DR5 as well as caspase- 8 and cleaved caspase-3 [36].

It is interesting to note that mitochondrial division inhibitor-1 (MDIVI-1), also known as dynamin 1-like (NDM1L), is able to enhance the sensitivity of human ovarian cancer cells to death receptor ligands including TRAIL, FAS ligands, and TNFA [37]. Importantly, the combination of TRAIL and NDM1L has no apparent cytotoxic effect on non-transformed human cells, indicating a significant therapeutic window. This effect is mediated by caspase- 8 and not by the two important pro-apoptotic Bcl-2 family proteins Bax and Bak [37].

Hypoxia is a major problem that impairs the sensitivity of human cancer cells to death by apoptosis. Certain miRNAs that regulate apoptotic genes including miR-210 can be induced by hypoxia, resulting in cell apoptosis. Tse et al. [38] observed a 
significant induction of miR-210 in primary ovarian follicular cells exposed to hypoxia, and gene ontology analysis further highlighted the potential roles of miR-210 in cell proliferation, cell differentiation, and cell apoptosis through a number of miR-210 target apoptotic genes, including TNFRSF10B/DR5, deleted in liver cancer 1 protein (DLC1), STE20-like serine/threonine-protein kinase (SLK), RNA binding motif protein 25 (RBM25), and ubiquitin-specificprocessing protease 7 (USP7) [38]. Moreover, ectopic expression of miR-210 would result in downregulation of these apoptotic genes. On the other hand, the inhibition of miR-210 promoted apoptotic cell death and the expression of apoptotic marker caspase 3 in follicular cells under hypoxic treatment, supporting the regulatory role of miR-210 in ovarian cell apoptosis [38].

Recently, it was shown that apoptosis induced by TRAIL in PC-3 cells is enhanced by inhibition of transient receptor potential melastain 7 (TRPM7), a bifunctional protein with dual structure of both ion channel and protein kinase, which participate in a wide variety of diseases including cancer [39]. The influence and potential function of TRPM7 on the PC-3 cells apoptosis induced by TNF-related apoptosis inducing ligand (TRAIL) was also demonstrated. The expression of TRPM7 is up-regulated in PC-3 cells after treating with TRAIL and subsequent induction of apoptosis. Furthermore, the suppression of TRPM7 by TRPM7 non-specific inhibitors not only markedly eliminated TRPM7 expression level, but also increased the apoptosis of TRAIL-treated PC-3 cells, which may be regulated by the phosphatidyl inositol 3-kinase/protein kinase B signaling pathway accompanied with up-regulated expression of cleaved caspase-3, TRAIL-receptor 1/DR4, and TRAIL-receptor 2/DR5 [39].

TNFRSF21 (death receptor-6, DR6) is an orphan TNF receptor superfamily member and is expressed ubiquitously with high expression in the lymphoid organs, heart, brain and pancreas. Ectopic expression of DR6 in some cell lines leads to apoptosis and activation of the JNK and NF- $\kappa \mathrm{B}$ pathways. Some tumor cells overexpress DR6, typically in conjunction with elevated anti-apoptosis molecules. DR6 show normal development with no gross pathology in any major organs. In the absence of DR6, B-cells show increased proliferation, cell division and cell survival upon mitogenic stimulation (anti-CD40 and LPS) [16]. Thus, DR6 plays an important regulatory role for the generation of adaptive immunity.
In addition, TNFRSF21 is highly expressed in many tumor cell lines and tumor samples. Interestingly, both of its transcriptional and cell surface expression are regulated by the NF- $\mathrm{KB}$ pathway and metalloproteinase in some tumor cell lines, respectively. The role of DR6 as an apoptosis-inducing receptor is less clear and perhaps cell type dependent [16]. It is interesting to note that DR6 can bind the amyloid precursor protein via the protein extracellular regions, inhibits synapse formation and is important for APP-induced dimerization and activation of cell surface TNFRSF21/DR6 [40].

Mirzaei et al. [41] have shown significant changes in the expression profile of apoptotic genes in the AGS (gastric adenocarcinoma), 5637 (bladder tumor), and U-87MG (brain tumor) cell lines transfected with OCT4B1, a newly discovered spliced variant of transcription factor OCT4, which is primarily expressed in pluripotent and tumor cells. This variant of transcription factor OCT4 is significantly overexpressed in tumors, where it endows an anti-apoptotic property to tumor cells. The expression of TNFRSF1A/TRADD, TNFRSF21/DR6, TNFRSF10B/DR5, TNFRSF11B (decoy receptor osteoprotegerin, and CASP7) is up-regulated in all three examined cell lines following OCT4B1 suppression with irrelevant siRNAs and down-regulated in cells transfected with OCT4B1 [41]. Thus, with some minor exceptions, the suppression of OCT4B1 caused up-regulation of pro-apoptotic and downregulation of anti-apoptotic genes in tumor cells. Jang et al. [42] studied effect of the suppression of adenine nucleotide translocase-2 (ANT2) by shorthairpin RNA (shRNA) on the resistance of breast cancer cells to TRAIL-induced apoptosis in vitro and in vivo in breast cancer cells, which frequently expressed high levels of ANT2. It was shown that ANT2 shRNA treatment sensitized MCF7, T47 D, and BT474 cells to TRAIL-induced apoptosis by upregulating the expression of TRAIL death receptors 4 and 5 (DR4/TNFRSF10A and DR5/TNFRSF10B) and down-regulating the TRAIL decoy receptor 2 (DcR2/TNFRSF10D). In MCF7 cells, ANT2 knockdown activated the stress kinase c-Jun N-terminal kinase (JNK), subsequently stabilizing and increasing the transcriptional activity of p53 by phosphorylating it [42]. Furthermore, ANT2 shRNA-induced overexpression of DR4, DR5 and TRAIL sensitization were blocked by a p53 inhibitor, suggesting that p53 activation plays an important role in the transcriptional up-regulation of these death receptors. 
However, ANT2 knockdown also up-regulated DR4 and DR5 in the p53-mutant cell lines BT474 and T47 $\mathrm{D}$ [42]. Treatment of the cells with a demethylation agent or JNK inhibitor prevented the ANT2 shRNAinduced down-regulation of DcR2 and activation of p53. In experiments in vivo using nude mice, ANT2 shRNA caused TRAIL-resistant MCF7 xenografts to undergo TRAIL-induced cell death, up-regulated DR4/TNFRSF10A and DR5/TNFRSF10B and down-regulated the TRAIL decoy receptor 2 (DcR2/ TNFRSF10D). Moreover, co-treatment with adenine nucleotide translocase-2 shRNA and TRAIL efficiently suppressed tumor growth in these mice [42].

At the same time, there is cell type specificity of signaling from membrane receptors to their downstream cell-type dependent transduction networks [43]. It was shown that similar response of most cells to the same stimulus presented high functional similarity. Likewise, in cancer cells most signaling networks were generally dysfunctional and less complete than in normal cells. However, glioma emerged hyper-activated the transduction mechanism in malignant state. Receptor ATP6AP2 and TNFRSF21 induced rennin-angiotensin and apoptosis signaling were found likely to explain the glioma-specific mechanism [43]. The ubiquitin-proteasome system (UPS) has been shown to regulate TRAILR members suggesting that pharmacological inhibition of the UPS may be a novel strategy to augment TRAIL-based therapies and increase efficacies. Recently, an inhibitor of proteasome deubiquitinase activity b-AP15 was identified, and exposure of tumor cell lines to this inhibitor resulted in increased TRAILR2 expression and enhanced sensitivity to TRAIL-mediated apoptosis and cell death in vitro and in vivo [11].

Therefore, tumor necrosis factor receptors and Fas-related death receptors play an important role in the regulation of apoptosis and cell proliferation through downstream cell-type dependent transduction networks and are regulated by multiple factors.

\section{Tumor necrosis factor-related decoy receptors}

In addition to death receptors, several decoy receptors have also been identified and include decoy receptor 1 (DcR1), also known as TNFRSF10C/ TRAILR3/TRID, DcR2, also known as TNFRSF10C/TRUNDD, DcR3, also known asTNFRSF6B, and DcR4, also known as TNFRSF11B or osteoprotegerin (OPG). The decoy receptors, which lack the pro-apoptotic death domain, do not transduce apoptotic signals but rather compete with the death receptors for ligand binding and thereby inhibit ligand-induced apoptosis [10, 14]. DcR1 is not capable of inducing apoptosis, and is thought to function as an antagonistic receptor that protects cells from TRAIL-induced apoptosis. This gene was found to be a p53-regulated DNA damage-inducible gene. However, p53 also regulates the expression of TRAIL decoy receptors DcR1 and DR2. Although the significance of p53-dependent regulation of decoy receptors remains unclear, evidence suggests that DcR1 appears to inhibit p53-mediated apoptosis. It is, therefore, possible that p53 may blunt its DR5dependent apoptotic effects by controlling the levels of decoy receptors. Pro-apoptotic ligand TRAIL engages the apoptotic machinery through two proapoptotic receptors, TRAILR1/DR4/TNFRSF10A and TRAILR2/DR5/TNFRSF10B. This cell death program is tightly controlled by two antagonistic receptors, TRAILR3/DcR1/TNFRSF10C and TRAILR4/DcR2/TNFRSF10D, both devoid of a functional death domain, an intracellular region of the receptor, required for the recruitment and the activation of initiator caspases. Upon TRAIL-binding, TRAILR4/DcR2 forms a heteromeric complex with the agonistic receptor TRAILR2/DR5 leading to reduced caspase- 8 activation and apoptosis [44]. The inhibitory decoy receptors (DcR1 and DcR2) coexpressed with death receptors (DR4 and DR5) on the same cell can block the transmission of the apoptotic signal and also regulate TRAIL sensitivity at a supracellular level and thus represent a mechanism by which the microenvironment can diminish tumor TRAIL sensitivity [10].

The tissue restricted expression of the decoy receptors on normal but not cancer cells provides a therapeutic rational for the development of selective TRAIL-mediated anti-tumor therapies. It was shown that the membrane expression of decoy receptors for TRAIL DcR1 and DcR2 is greater in the normal endometrium than endometrioid endometrial cancer [45]. Moreover, the TNFRSF10C copy number variation in patients with colorectal cancer is associated with distant metastatic disease [46]. DcR2/ TRAILR4 promotes tumor growth and resistance to apoptosis in cervical carcinoma HeLa cells through AKT, may contribute to cervical carcinogenesis [44]. Furthermore, this decoy receptor can directly inhibit TRAIL-induced cell death at the membrane and also trigger the activation of signaling pathways leading 
to cell survival and proliferation in HeLa cells. Shin et al. [46] demonstrate that the TNFRSF10C/DcR1 as well as TNFRSF10A/DR4 and TNFRSF10B/ DR5 participate in apoptotic and antioxidant effects of vitisin A, derived from wine grapes, the underlying antitumor mechanism in prostate cancer cells. Upregulation of TNFRSF10B/DR5 and production of reactive oxygen species mediate sensitization of PC-3 prostate cancer cells to TRAIL induced apoptosis by vitisin A [47]. Combined treatment of PC-3 cells with vitisin A and TRAIL increased the production of reactive oxygen species, DR5 promoter activity, its cell surface expression, and enhanced cytotoxicity. Furthermore, the reactive oxygen species inhibitor NAC and silencing of DR5 by siRNA transfection inhibited the ability of combination to generate ROS [47].

Recently, it was shown that epigenetic inactivation of TRAIL decoy receptors TNFRSF10C and TNFRSF10D in the majority of cervical cancer patients downregulated expression of these decoy receptors and confers sensitivity to TNFRSF10C/ trail-cisplatin combination therapy in cervical cancer [48]. Moreover, the cervical cancer cell lines harboring epigenetic inactivation of TRAIL decoy receptors effectively activate downstream caspases suggesting a critical role of inactivation of these genes in efficient execution of extrinsic apoptotic pathway and therapy response. Analysis of TNFRSF10D/ DcR2 DNA-methylation status in melanoma patients revealed that methylated TNFRSF10D is associated with the survival of melanoma patients [49]. There is data that the increased DcR2 protein levels might play a role in TRAIL resistance in solid tumors and that hypoxia, which is an important feature of solid tumors and renders tumor cells resistant to some chemotherapeutic agents, including TRAIL, is responsible for this effect [50]. Thus, hypoxia upregulated DcR2 protein expression on the cell surface membrane in five different human colon cancer cell lines (HCT116, HT29, SW480, SW620, and WiDr). In contrast, hypoxia had no effect on TNFRSF10A/ DR4, TNFRSF10B/DR5, or TNFRSF10C/DcR1 protein levels [50]. Furthermore, hypoxia-inducible factor $1 \alpha$ played a crucial role in up-regulation of the transcription of DcR2, but that neither p53 nor $\mathrm{NF}-\kappa \mathrm{B}$ contributed to this regulation. Moreover, TRAIL-induced cell death was attenuated under hypoxic conditions [50].

Mansour et al. [51] have recently shown that decoy receptor 1 mediates malignant glioma resistance to temozolomide, which is used widely to treat this tumor. Resistance to temozolomide has been related to the induction of anti-apoptotic proteins including the transcription factor NF- $\mathrm{KB}$, which has been suggested to participate in promoting the survival of cells exposed to chemotherapy. It was shown that the decoy receptor DcR1 as a temozolomide response gene induced by a mechanism relying upon p50/NF$\kappa B 1$ through NF- $\kappa B-b i n d i n g$ site identified in the promoter of TNFRSF10C/DcR1 gene [51]. Moreover, both loss-of-function and gain-of-function studies reveal that the atypical $\mathrm{I} \kappa \mathrm{B}$ protein, $\mathrm{Bcl} 3$, is also required for induction of DcR1 by temozolomide.

DcR3/TNFRSF6B also protects against apoptosis because it can neutralize the cytotoxic ligands TNFS14/LIGHT, TNFSF15 and TNFSF6/FASL. Higher DcR3 expression was related to the status of invasion, lymph node metastasis and recurrence in bladder urothelial carcinoma [52]. Overexpression of DcR3 was found in bladder urothelial carcinomas and cell lines, with significant elevation as compared to normal bladder tissues and negatively correlated with caspase- 3 and positively associated with $\mathrm{Bcl}-2$, VEGF, and p53. Thus, decoy receptor 3 may play an important role as an oncogene in tumorigenesis and progress of bladder urothelial carcinoma via influencing related pathways of apoptosis, proliferation and angiogenesis [52]. DcR3 is also involved in development and prognosis of female reproductive cancers, including cervical cancer, ovarian cancer, and breast cancer [53]. Recently, it was shown that the alteration of decoy receptor 3 leads to resistance of idiopathic pulmonary fibrosis fibroblasts to Fas ligand-dependent apoptosis [54]. These fibroblasts interact with collagen matrix, and aberrantly activated Akt increases DcR3 expression and protects these cells from the FasL-dependent apoptotic pathway. TNFRSF6B is also induced by TNFA-induced protein 8 , a recently identified protein that is considered to be associated with various malignancies, including esophageal, breast, gastric, and pancreatic cancer [55]. The expression of DcR3 is regulated by the mitogen-activated protein kinase (MAPK)/MAPK kinase/extracellular signal-regulated kinase (ERK) signaling pathway. The expression of TNFA-induced protein $8, \mathrm{ERK} 1 / 2$ and DcR3 in the tumor tissues of GC was significantly increased compared with paracarcinoma tissues and TNFA-induced protein 8 expression positively correlated with DcR3 and ERK1/2 levels, which may be involved in the cell apoptosis of gastric and pancreatic cancer $[55,56]$. 
The level of DcR3 protein and ERK1/2 phosphorylation in pancreatic carcinoma cells is up-regulated and RNAi knockdown of DcR3 expression reduced resistance to FasL-induced apoptosis and elevated expression of caspase 3, 8 and 9 as well as reduced ERK1/2 phosphorylation [56]. Thus, DcR3/TNFRSF6B enhances ERK1/2 phosphorylation and opposes FasL signaling in pancreatic cancer cells.

DcR4/TNFRSF11B, also known as osteoprotegerin (OPG), acts as decoy receptor for TNFSF11/ RANKL and thereby neutralizes its function in osteoclastogenesis. TNFRSF11B may also act as a soluble decoy receptor for TNFSF10/TRAIL, plays an inhibitory role in TRAIL-induced cell apoptosis and protects against TRAIL-mediated apoptosis [57]. OPG was initially discovered to contribute to homeostasis of bone turnover due to its capability of binding to receptor activator of nuclear factor$\kappa \mathrm{B}(\mathrm{NF}-\mathrm{kB})$, but apart from bone turnover, OPG plays important and diverse roles in many biological functions. Upon TRAIL-binding, OPG forms a heteromeric complex with the agonistic receptor TRAILR2/DR5 leading to reduced caspase-8 activation and apoptosis. Along with inhibiting TRAIL induced apoptosis, it can induce proliferation by binding to various cell surface receptors and thus turning on the canonical cell survival and proliferative pathways as well as induces angiogenesis, one of the hallmarks of cancer, thus facilitating cancer progression, especially breast cancer [57]. Furthermore, osteoprotegerin has tumor-promoting roles in the pathogenesis of lymphangioleiomyomatosis, contributes to the metastatic potential of cells with a dysfunctional TSC2 tumor-suppressor gene, selectively induced migration and stimulates proliferation of cells cultured from explanted lymphangioleiomyomatosis lungs, which is characterized by cystic lung destruction, lymphatic infiltration, and abdominal tumors [58]. The expression of OPG mRNA was significantly increased in lung nodules and serum OPG level was ssignificantly higher in lymphangioleiomyomatosis patients than in normal volunteers.

Bosman et al. [59] have shown that recombinant human tumor necrosis factor-related apoptosisinducing ligand (rhTRAIL) D269H/E195R is specific for TNFRSF10B/DR5 and displays a significantly decreased affinity to osteoprotegerin and overcomes TRAIL resistance mediated by the bone marrow microenvironment, which provides important signals for the survival and proliferation of hematopoietic and malignant cells. OPG also participates in osteoclast differentiation induced by vascular endothe- lial growth factor, a key cytokine for angiogenesis, which increased the osteoblastic the receptor activator of nuclear factor kappa-B ligand (RANKL)/OPG ratio and induces osteoblast proliferation, migration, and invasion potentials in vitro [60].

Moreover, DcR2/TRAILR4 promotes tumor growth and resistance to apoptosis in cervical carcinoma HeLa cells and can also exhibit, in a ligand independent manner, signaling properties in the cervical carcinoma cell line HeLa, through Akt [44]. Ectopic expression of TNFRSF10D/TRAILR4 in HeLa cells induced morphological changes, with cell rounding, loss of adherence and markedly enhanced cell proliferation in vitro and tumor growth in vivo, but disruption of the PI3K/Akt pathway using the pharmacological inhibitor LY294002, siRNA targeting the $\mathrm{p} 85$ regulatory subunit of phosphatidylinositol-3 kinase, or by PTEN over-expression, partially restored TRAIL-mediated apoptosis in these cells [44]. Moreover, the Akt inhibitor, LY294002, restituted normal cell proliferation index in HeLa cells expressing TNFRSF10D. TNFRSF10D is a p53 target gene and its overexpression or $C C N G 2$ gene, a negative cell cycle regulator, induces cell cycle arrest and may contribute to thiopurine resistance [61]. At the same time, cross-platform array screening identifies TNFRSF10D and thrombospondin 1 as well as ubiquitin carboxy-terminal hydrolase L1 as genes frequently silenced by methylation in melanoma, which was shown in a large panel of melanoma cell lines and resected melanomas [62].

Decoy receptors also regulate TRAIL sensitivity at a supracellular level and thus represent a mechanism by which the microenvironment can diminish tumor TRAIL sensitivity. Moreover, these receptors do not only act in a cell-autonomous or cis-regulatory manner, but also exert trans-cellular regulation originating from stromal cells and affect tumor cells, highlighting the potent inhibitory effect of decoy receptors in the tumor tissue and the necessity of selective targeting of the two death-inducing TRAIL receptors to maximize efficacy [10, 14]. Todorova et al. $[63,64]$ have shown that TNF-related apoptosis-inducing ligand receptor 4 is controlled by poly(ADP-ribose) polymerase-13 (PARP13), also known as ZC3HAV1 and zinc-finger antiviral protein (ZAP), which is an antiviral factor, regulates cellular mRNA post-transcriptionally and functions as a pro-apoptotic factor by destabilizing TRAILR4 transcript.PARP13 binds RNA via its four CCCH-type zinc-finger domains and targets it for degradation by recruiting cellular messenger RNA decay factors 
such as the exosome complex and XRN1. PARP13 binds to and regulates cellular mRNAs in the absence of viral infection. Knockdown of PARP13 results in the misregulation of hundreds of transcripts including TRAILR4/DcR2. PARP13 destabilizes TRAILR4 mRNA post-transcriptionally in an exosome-dependent manner by binding to a region in its $3^{\prime}$ untranslated region. As a consequence, PARP13 represses TRAILR4 expression and increases cell sensitivity to TRAIL-mediated apoptosis, acting as a key regulator of the cellular response to TRAIL [63]. Post-transcriptional regulation of RNA is an important mechanism for activating and resolving cellular stress responses. Moreover, these functions of PARP13 are important components of the cellular response to stress. In addition, the ability of PARP13 to restrict oncogenic viruses and to repress the prosurvival cytokine receptor tumor necrosis factor (TNF)-related apoptosis-inducing ligand receptor 4 suggests that it can be protective against malignant transformation and cancer development [64].

Recently, it was shown that the expression of TRAIL and TRAIL receptors as well as TRAILinduced apoptosis is significantly increased in hepatocellular carcinoma by interferon- $\alpha$ and celecoxib, a cyclooxygenase- 2 inhibitor, respectively, because cyclooxygenase- 2 is overexpressed in this carcinoma cells and is considered to play a role in hepatocarcinogenesis [65]. Thus, interferon- $\alpha$ and cyclooxygenase-2 inhibitor synergistically inhibit cell proliferation in a dose- and time-dependent manner and cooperatively mediateTRAIL-induced apoptosis in hepatocellular carcinoma [66]. Moreover, the regulation of interferon- $\alpha$ - and COX-2 inhibitor-induced cell death is impaired in a subset of TRAIL-resistant cells. It was also shown that doxorubicin-induced recruitment of death receptor 5 to the cell surface impacts the enhanced apoptotic effect that can be longitudinally monitored by apoptosis imaging [66]. It is interesting to note that pancreatic tumor samples have increased levels of nuclear TRAILR2/ DR5/TNFRSF10B and that this form of TRAILR2 inhibits maturation of the microRNA let-7 in pancreatic cancer cell lines and increases their proliferation [67]. Moreover, knockdown of TRAILR2 increased Drosha-mediated processing of the let-7 microRNA precursor primary let-7 (resulting in increased levels of mature let-7), reduced levels of the let-7 targets (LIN28B and HMGA2), and inhibited cell proliferation. Nuclear TRAIL-R2 inhibits maturation of the microRNA let-7 in pancreatic cancer cell lines and increases their proliferation [67]. Gupta et al. [6] found that a limonoid tetranortriterpene, azadirone, sensitizes human cancer cells to TRAIL, induces death receptors DR5 and DR4 signaling, down-regulates of cell survival proteins, and upregulates of proapoptotic proteins.

Thus, targeting TRAIL and TRAIL receptors, which control many aspects of tumor cell death (Fig. 1), is important in the treatment of cancer because defective apoptosis contributes to the survival of cancer cells [10, 13, 14, 19, 68]. TRAIL-targeted therapy with an outlook towards the future included recombinant human proteins, small molecules and agonistic monoclonal antibodies targeting death receptors that trigger TRAIL-mediated apoptosis.

\section{Endoplasmic reticulum stress modulates the expression of TNF-related genes}

Recently, it was demonstrated the expression of most TNFA-related genes responsible for endoplasmic reticulum stress, which had been shown to trigger cell proliferation through reprogramming genome and cell death through apoptosis [69-71]. Apoptosis related proteins TNFRSF10D/TRAILR4, TNFRSF10B/TRAILR2/DR5, TNFRSF21/DR6, TRADD, TNFRSF11B/OPG, TNFAIP1, TNFAIP3, and TNFSF7/CD70 were among them. The endoplasmic reticulum (ER) is the primary organelle able to activate a distinct cellular stress response, termed the unfolded protein response in which an aggregate of misfolded proteins triggers activation of a complex set of signaling pathways to execute a resolution to the causative stress. Malignant tumors utilize the endoplasmic reticulum stress response to adapt to stressful, environmental conditions [72-74]. The rapid growth of solid tumors generates microenvironmental changes in association to hypoxia, nutrient deprivation and acidosis, which induce new blood vessels formation and cell proliferation and surviving $[72,74]$. Those processes rely on the activation of endoplasmic reticulum stress signalling pathways. UPR is mediated by three interconnected, endoplasmic reticulum-resident sensors. IRE1 (inositol requiring enzyme-1), also known as ERN1 (endoplasmic reticulum to nucleus signaling 1), is the most evolutionary conserved sensor that responds to protein misfolding with a highly tuned program aimed to either resolve the stress or direct the cell towards apoptosis in the case rectification is not viable; thus making it a key regulator of life and death processes $[71,73,75,76]$. 
Inhibition of IRE1 significantly decreases glioma cell proliferation and tumor growth and affects the expression of numerous genes responsible for regulation of cell proliferation, surviving and apoptosis including TNFA related genes $[69,70,75$, 77-84]. Thus, inhibition of IRE1 signaling enzyme activity causes a strong increase (more than 8 -fold) in the levels of TNFRSF21 mRNA, which is known as death receptor 6, in U87 glioma cells (Fig. 2). It is interesting to note that the changes observed in the above studied gene, which has relation to TNFdirected apoptosis, correlate well with slower cell proliferation in cells harboring dnIRE1, attesting to the fact that endoplasmic reticulum stress is a necessary component of malignant tumor growth and cell survival $[72,74,80,83]$. There is data that TNFRSF21/DR6 induced apoptosis through a new pathway that is different from the type I and type II pathways through interacting with Bax protein [85]. Moreover, B-cells lacking TNFRSF21/DR6 show increased proliferation rate and cell survival upon mitogenic stimulation [16]. However, this gene is highly expressed in many tumor cell lines and tumor samples and the role of TNFRSF21/DR6 as an apoptosis-inducing receptor is less clear and perhaps cell type dependent.
Another death receptor, DR5/TNFRSF10B, is a receptor for TRAILR2 and can initiate the extrinsic apoptotic pathway characterized by the recruitment of death domains, assembly of the death-inducing signaling complex (DISC), caspase activation and ultimately apoptosis. At the same time, TNFRSF10B/DR5 mRNA expression is down-regulated upon inhibition of IRE1 signaling enzyme (Fig. 2). Therefore, the changes observed in the TNFRSF $10 B$ gene, as initiator of apoptosis, do not correlate with slower cell proliferation in cells harboring dnIRE1. It is possible that TNFRSF10B/DR5 facilitate only endoplasmic reticulum stress-mediated apoptosis and inhibition IRE1-mediated endoplasmic reticulum stress signaling causes down-regulation of this gene expression, because recently it was shown that DDIT3/CHOP and KAT2A proteins regulate TNFRSF10B expression and endoplasmic reticulum stress-mediated apoptosis in human lung cancer cells via formation of the KAT2A.DDIT3 phospho-JUN complex and knockdown of KAT2A down-regulated TNFRSF10B [86].

At the same time, significant up-regulation of TRAILR4/TNFRSF10D/DcR2 and TNFRSF11B/ DcR4/OPG in glioma cells upon inhibition of IRE1 was observed (Fig. 2). These decoy receptors lack

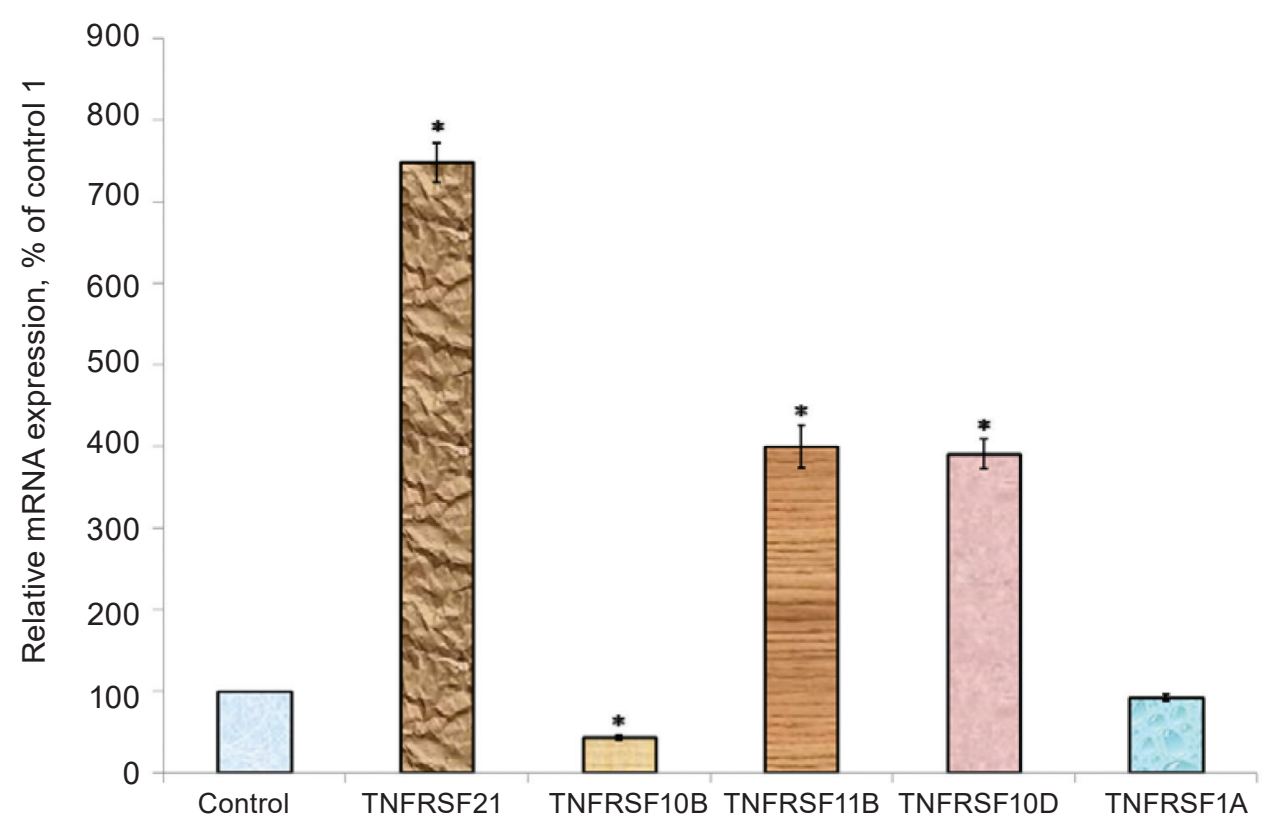

Fig. 2. Expression of DR6/TNFRSF21, DR5/TNFRSF10B, DcR4/OPG/TNFRSF11B, TNFRSF10D/DcR2/ TRAILR4, and TNFRSF1A/TNFR1 mRNAs in glioma cell line U87 (Vector) and its sublines with a deficiency of both protein kinase and endoribonuclease of the signaling enzyme IRE1 (dnIRE1) measured by qPCR. The expression values of TNF receptor superfamily member $m R N A$ s were normalized to $\beta$-actin $m R N A$ expression and represented as percent control (vector, 100\%); mean $\pm S E M ; n=4 ; * P<0.001$ versus control [69] 
the pro-apoptotic death domain, could not induce apoptosis and have been shown to play an inhibitory role in TRAIL-induced cell apoptosis [11, 44, 57]. The induction of TNFRSF10D and TNFRSF11B mRNAs in glioma cells upon inhibition of IRE1 correlates with down-regulation of TNFRSF10B/DR5. Similar negative correlation was observed in breast cancer cells treated by short-hairpin RNA for suppression of adenine nucleotide translocase-2 (ANT2) [42]. Suppression of ANT2 restores susceptibility of breast cancer cells to TRAIL-induced apoptosis by activating JNK and modulating TRAIL receptor expression: up-regulating the expression of TRAIL death receptors 4 and 5 and down-regulating the TRAILR4/DcR2 [42].

Interestingly, the silencing of TNFRSF10D is related to melanoma genesis [49]. It is possible that TRAILR4/TNFRSF10D as well as TRAILR2/ TNFRSF10B have relation to regulation of endoplasmic reticulum stress-mediated apoptosis. Moreover, modulation of CCAAT/enhancer binding protein homologous protein (CHOP)-dependent TRAILR2/ TNFRSF10B/DR5 expression by nelfinavir sensitizes glioblastoma multiform cells to tumor necrosis factor-related apoptosis-inducing ligand (TRAIL) [70]. Therefore, a better understanding of the mechanisms underlying TRAILR4/TNFRSF10D as well as TRAILR2/TNFRSF10B is required.

Tian et al. [70] have shown that nelfinavir treatment led to endoplasmic reticulum stress-induced up-regulation of the TNFRSF10B/DR5 expression. This transactivation was mediated by the transcription factor CCAAT/enhancer binding protein homologous protein (CHOP). Furthermore, endoplasmic reticulum stress-induced ATF4 up-regulation was responsible for modulation of CHOP. In contrast, DR4 receptor expression was unchanged by nelfinavir treatment. Combining nelfinavir with TRAIL led to a significantly enhanced level of apoptosis that was abrogated by siRNA silencing of DR5. Thus, nelfinavir-induced endoplasmic reticulum stress modulates DR5 expression in human glioblastoma multiforme cells and can enhance TRAIL efficacy [70].

Endoplasmic reticulum stress-induced sensitization of p53-deficient human colon cancer cells to TRAIL-mediated apoptosis through upregulation of DR5 was observed by Edagawa et al. [87]. They have shown that the stress response gene ATF3 is required for endoplasmic reticulum stress-mediated TNFRSF10B/DR5 induction upon zerumbone and celecoxib in these colorectal cancer cells. Both agents activated PERK-eIF2 $\alpha$ kinases and induced the expression of activating transcription factor 4 (ATF4)-CCAAT enhancer-binding protein (C/EBP) homologous protein, which were remarkably suppressed by reactive oxygen species scavengers. In the absence of ATF3, the induction of DR5 mRNA and protein was abrogated significantly, and this was associated with reduced cell death by cotreatment of TRAIL with zerumbone and celecoxib [87]. By contrast, exogenous expression of ATF3 caused a more rapid and elevated expression of DR5, resulting in enhanced sensitivity to apoptotic cell death by TRAIL/zerumboneor TRAIL/celecoxib. A reporter assay demonstrated that at least two ATF/cAMP response element motifs as well as C/EBP homologous protein motif at the proximal region of the human DR5 gene promoter were required for zerumbone-induced DR5 gene transcription. Thus, ATF3 is an essential transcription factor for $\mathrm{p} 53$-independent TNFRSF10B/ DR5 induction upon both zerumbone and celecoxib treatment and this may be a useful biomarker for TRAIL-based anticancer therapy [87]. Essential role of ATF3 transcription factor in synergistic cancer cell killing by a combination of histone deacetylase (HDAC) inhibitors and agonistic anti-DR5 antibody through ER stress in human colon cancer cells was also shown by Liu et al. [88]. In this case they used the combination of TRAIL/agonistic antiDR5 monoclonal antibody and agents that increase the expression of DR5, which is expected as a novel anticancer therapeutic strategy. It was shown that six different HDAC inhibitors activated endoplasmic reticulum stress sensor PERK and eIF26 and induced the ATF4/ATF3/CHOP pathway in p53-deficient human colon cancer cells. This resulted in an increased expression of DR5 on the cell surface and sensitized cells to apoptosis by agonistic anti-DR5 monoclonal antibody. Stress response gene ATF3 was required for efficient DR5 induction by HDAC inhibitors, and DR5 reporter assay showed that ATF3 play crucial role for the HDAC inhibitors-induced activation of death receptor 5 gene transcription [88].

Recently, it was shown that hypoxia, which is a major problem that impairs the sensitivity of human cancer cells to death by apoptosis, affects the expression of most TNFA related genes responsible for apoptosis in gene specific manner and that inhibition of IRE1 significantly modulates effect of hypoxia on these genes expression in glioma cells (Fig. 3 and 4) [69]. 


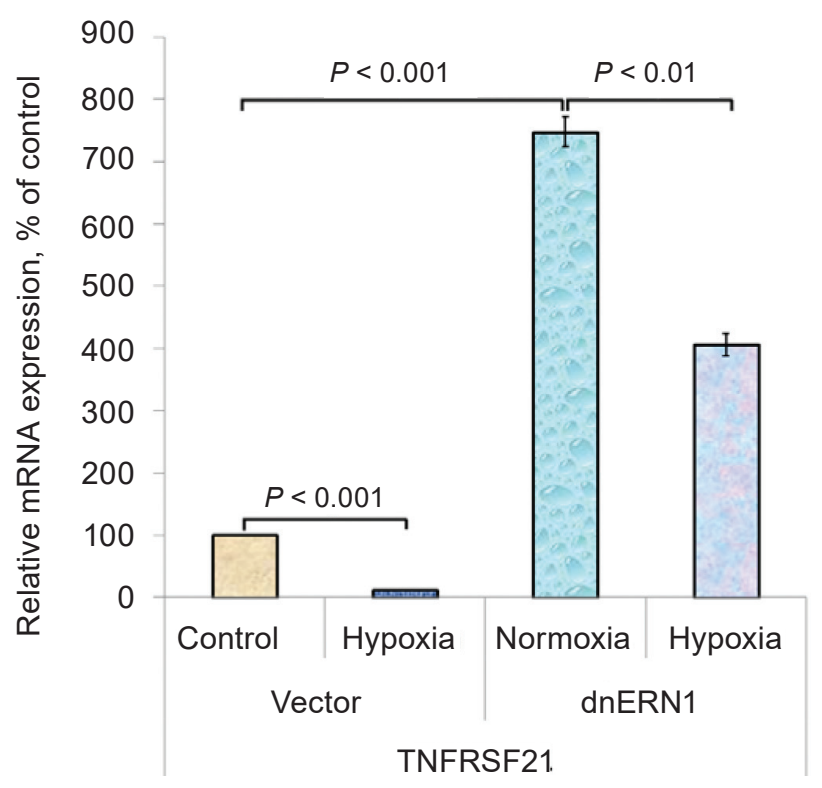

Fig. 3. Effect of hypoxia (3\% oxygen -16 h) on the expression levels of TNFRSF21/DR6 mRNA (by $q P C R$ ) in control glioma cells (Vector) and cells with a deficiency of IRE1 (dnIRE1). TNFRSF21 mRNA expressions values were normalized to $\beta$-actin $m R N A$ expression and represented as percent control (control gliom a cells transfected by vector, 100\%); mean \pm SEM; $n=4$ [69]

Hypoxia strongly suppress the expression of TNFRSF21/DR6 mRNA (8.3-fold) in control glioma cells and inhibition of IRE1 significantly reduces effect of hypoxia on this mRNA expression (Fig. 3). Thus, TNFRSF21 gene expression is responsive to hypoxia preferentially through IRE1 signaling pathway of endoplasmic reticulum stress [69]. At the same time, hypoxia slightly down-regulates the expression level of TNFRSF11B/DcR4 mRNA in control glioma cells (-19\%), but inhibition of IRE1 strongly enhances this effect of hypoxia (2.4 fold down-regulation) (Fig. 4). It is interesting to note that the expression of genes encoding for TNFRSF10B/ DR5/TRAILR2 as well as TNFRSF1A/TNFR1 does not change significantly in control glioma cells treated by hypoxia; however, inhibition of IRE1 introduces sensitivity of these gene expressions to hypoxia (up-regulation 39 and $47 \%$, respectively) [69]. These results demonstrate that the expression of TNFRSF1OB and TNFRSF1A genes is resistant to hypoxia in wild type glioma cells, but inhibition of the IRE1 activity leads to up-regulation of these genes expression. At the same time, the expression level of TNFRSF10D/TRAILR4/DcR2 mRNA is up-

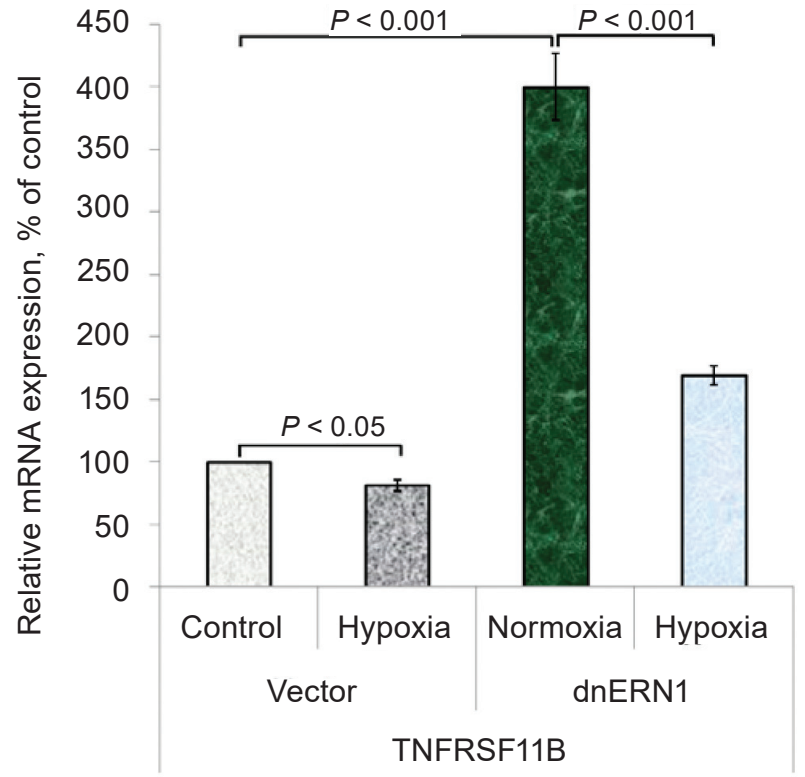

Fig. 4. Effect of hypoxia (3\% oxygen -16 h) on the expression levels of TNFRSF11B/DcR4/OPG mRNA (by qPCR) in control glioma cells (Vector) and cells with a deficiency of IRE1 (dnIRE1). TNFRSF11B mRNA expressions values were normalized to $\beta$-actin mRNA expression and represented as percent control (control glioma cells transfected by vector, $100 \%)$; mean \pm SEM; $n=4$ [69]

regulated by hypoxia in glioma cells independent of IRE1 signaling enzyme function [69]. There is data that the increased DcR2 protein levels might play a role in TRAIL resistance in solid tumors and that hypoxia, as an important feature of solid tumors, and renders tumor cells resistant to some chemotherapeutic agents, including TRAIL, up-regulates this decoy receptor, but has no effect on TNFRSF10A/ DR4, TNFRSF10B/DR5, or TNFRSF10C/DcR1 protein levels [50].

Because TRAIL-mediated apoptosis of cancer cells is responsible for endoplasmic reticulum stress and oxidative stress new approaches are created: anticancer drugs for the modulation of these stresses $[89,90]$. It is important that targeting of endoplasmic reticulum stress response induced apoptosis in gliomas [89]. The endoplasmic reticulum functions as a multifunctional organelle and as a wellorchestrated protein-folding unit. It consists of sensors which detect stress-induced unfolded/misfolded proteins and it is the place where protein folding is catalyzed with chaperones. Protein folding and the generation of reactive oxygen species as a protein oxidative byproduct in endoplasmic reticulum are 
crosslinked. An endoplasmic reticulum stress-induced response also mediates the expression of the apoptosis-associated gene $\mathrm{CHOP}$ and death receptor 5. The endoplasmic reticulum stress induces the upregulation of tumor necrosis factor-related apoptosis inducing ligand (TRAIL) receptor and opening new horizons for therapeutic research [90]. These findings can be used to maximize TRAIL-induced apoptosis in xenografted mice. This review summarizes the current understanding of the interplay between ER stress and ROS. It is important that natural products and drugs have shown potential in regulating endoplasmic reticulum stress and reactive oxygen species in different cancer cell lines. Drugs as inducers and inhibitors of ROS modulation may respectively exert inducible and inhibitory effects on endoplasmic reticulum stress and unfolded protein response. Reconceptualization of the molecular crosstalk among ROS modulating effectors and endoplasmic reticulum stress will lead to advances in anticancer therapy [89].

To date, the majority of studies on TRAIL receptors have explored the role of these receptors as initiators of apoptosis. However, sporadic reports also suggest that TRAIL receptors can lead to other outcomes such as cytokine and chemokine production, cell proliferation and cell migration. Indeed, although transformed cells frequently express TRAIL, most do not undergo apoptosis upon engagement of these receptors, and a significant effort has been devoted toward exploring how to sensitize such cells to the pro-apoptotic effects of death receptor stimulation [41, 85, 91-93].

\section{РОЛЬ РЕЦЕПТОРІВ ТNF ТА ТNF-ЗАЛЕЖНИХ ЛІГАНДІВ, ЩО ІНДУКУЮТЬ АПОПТОЗ, ЗА РОСТУ ПУХЛИН}

\author{
О. Г. Мінченко, Д. О. Цимбал', \\ Д. О. Мінченко ${ }^{1,2}$, О. О. Ратушна
}

${ }^{1}$ Інститут біохімії ім. О. В. Палладіна Національної академії наук України, Київ; e-mail: ominchenko@yahoo.com

${ }^{2}$ Національний медичний університет ім. О. О. Богомольця, Київ, Україна

Суперродина рецепторів фактора некрозу пухлин (TNF) та TNF-залежних лігандів, що індукують апоптоз, відіграють важливу роль у реалізації функції TNF і контролюють ріст пухлин. Залежні від TNF шляхи регуляції контро- люються сигналами, опосередкованими стресом ендоплазматичного ретикулума, який відіграє ключову роль у контролі проліферації клітин та росту пухлин. Більше того, пригнічення IRE1 (inositol requiring enzyme-1), який є центральним медіатором стресу ендоплазматичного ретикулума і значною мірою відповідає за проліферацію і апоптоз клітин, опосередковує пригнічення росту пухлин шляхом специфічних змін в експресії генів. Серед них важливе місце займають ті гени, що кодують транскрипційні фактори, пухлинні супресори, а також протеїни, відповідальні за ангіогенез і апоптоз, включаючи суперродину рецепторів TNF та TNFзалежних лігандів, які індукують апоптоз. Таким чином, зміни рівня експресії TNF-залежних генів, що кодують протеїни суперродини рецепторів TNF та TNF-залежних лігандів можливо віддзеркалюють метаболічне репрограмування пухлинних клітин за умов інгібування IRE1-опосередкованого сигналювання стресу ендоплазматичного ретикулума і корелюють iз пригніченням проліферації клітин гліоми.

К люч о в $\quad$ с ло в а: суперродина рецепторів TNF, TRAIL, декой-рецептори, пригнічення IRE1, клітини гліоми.

\section{РОЛЬ РЕЦЕПТОРОВ ТNF И ТNF-3АВИСИМЫХ ЛИГАНДОВ, ИНДУЦИРУЮЩИХ АПОПТОЗ, ПРИ РОСТЕ ОПУХОЛЕЙ}

\author{
О. Г. Минченко , Д. О. Цимбал \\ Д. О. Минченко ${ }^{1,2}$, О. О. Ратушна ${ }^{1}$
}
${ }^{1}$ Институт биохимии им. А. В. Палладина Национальной академии наук Украины, Киев; e-mail: ominchenko@yahoo.com
${ }^{2}$ Национальный медицинский университет им. А.А. Богомольца, Киев, Украина

Суперсемейство рецепторов фактора некроза опухолей (TNF) и TNF-зависимых лигандов, индуцирующих апоптоз, играют важную роль в реализации функции TNF и контролируют рост опухолей. Зависимые от TNF пути регуляции контролируются сигналами, опосредованными стрессом эндоплазматического ретикулума, который играет ключевую роль в контроле пролиферации клеток и роста опухолей. Более того, угнетение IRE1 (inositol requiring enzyme-1), который является центральным медиатором 
стресса эндоплазматического ретикулума и в значительной степени отвечает за пролиферацию и апоптоз клеток, опосредует угнетение роста опухолей путем специфических изменений в экспрессии генов. Среди этих генов важное место занимают те, которые кодируют транскрипционные факторы, супрессоры опухолей, а также протеины, ответственные за ангиогенез и апоптоз, включая суперсемейство рецепторов TNF и TNF-зависимых лигандов, индуцирующих апоптоз. Таким образом, изменения уровня экспрессии TNF-зависимых генов, которые кодируют протеины суперсемейства рецепторов TNF и TNF-зависимых лигандов возможно отображают метаболическое репрограммирование опухолевых клеток при ингибировании опосредованного IRE1 сигналинга стресса эндоплазматического ретикулума и коррелируют с угнетением пролиферации клеток глиомы.

К люче в ы е с лов в: суперсемейство рецепторов TNF, TRAIL, декой-рецепторы, угнетение IRE1, клетки глиомы.

\section{References}

1. Lebrec H, Ponce R, Preston BD, Iles J, Born TL, Hooper M. Tumor necrosis factor, tumor necrosis factor inhibition, and cancer risk. Curr Med Res Opin. 2015; 31(3): 557-574.

2. Jang MK, Kim HS, Chung YH. Clinical aspects of tumor necrosis factor- $\alpha$ signaling in hepatocellular carcinoma. Curr Pharm Des. 2014; 20(17): 2799-2808.

3. Waters JP, Pober JS, Bradley JR. Tumour necrosis factor and cancer. J Pathol. 2013; 230(3): 241248.

4. Isaac ST, Tan TC, Polly P. Endoplasmic Reticulum Stress, Calcium Dysregulation and Altered Protein Translation: Intersection of Processes That Contribute to Cancer Cachexia Induced Skeletal Muscle Wasting. Curr Drug Targets. 2016; 17(10): 1140-1146.

5. Chu WM. Tumor necrosis factor. Cancer Lett. 2013; 328(2): 222-225.

6. Song Y, Buchwald P. TNF superfamily proteinprotein interactions: feasibility of smallmolecule modulation. Curr Drug Targets. 2015; 16(4): 393-408.

7. Kitson J, Raven T, Jiang YP, Goeddel DV, Giles KM, Pun KT, Grinham CJ, Brown R, Farrow SN. A death-domain-containing receptor that mediates apoptosis. Nature. 1996; 384(6607): 372-375.

8. Cullen SP, Martin SJ. Fas and TRAIL 'death receptors' as initiators of inflammation: Implications for cancer. Semin Cell Dev Biol. 2015; 39: 26-34.

9. de Miguel D, Lemke J, Anel A, Walczak H, Martinez-Lostao L. Onto better TRAILs for cancer treatment. Cell Death Differ. 2016; 23(5): 733-747.

10. O'Leary L, van der Sloot AM, Reis CR, Deegan S, Ryan AE, Dhami SP, Murillo LS, Cool RH, Correa de Sampaio P, Thompson K, Murphy G, Quax WJ, Serrano L, Samali A, Szegezdi E. Decoy receptors block TRAIL sensitivity at a supracellular level: the role of stromal cells in controlling tumour TRAIL sensitivity. Oncogene. 2016; 35(10): 1261-1270.

11. Sarhan D, D'Arcy P, Lundqvist A. Regulation of TRAIL-receptor expression by the ubiquitinproteasome system. Int J Mol Sci. 2014; 15(10): 18557-18573.

12. Dai X, Zhang J, Arfuso F, Chinnathambi A, Zayed ME, Alharbi SA, Kumar AP, Ahn KS, Sethi G. Targeting TNF-related apoptosisinducing ligand (TRAIL) receptor by natural products as a potential therapeutic approach for cancer therapy. Exp Biol Med (Maywood). 2015; 240(6): 760-773.

13. Fulda S. Tumor-necrosis-factor-related apoptosis-inducing ligand (TRAIL). Adv Exp Med Biol. 2014; 818: 167-180.

14. Mahalingam D, Szegezdi E, Keane M, de Jong S, Samali A. TRAIL receptor signalling and modulation: Are we on the right TRAIL? Cancer Treat Rev. 2009; 35(3): 280-288.

15. Walczak H, Haas TL. Biochemical analysis of the native TRAIL death-inducing signaling complex. Methods Mol Biol. 2008; 414: 221-239.

16. Benschop R, Wei T, Na S. Tumor necrosis factor receptor superfamily member 21 : TNFR-related death receptor-6, DR6. Adv Exp Med Biol. 2009; 647: 186-194.

17. Screaton GR, Xu XN, Olsen AL, Cowper AE, Tan R, McMichael AJ, Bell JI. LARD: a new lymphoid-specific death domain containing receptor regulated by alternative pre-mRNA splicing. Proc Natl Acad Sci USA. 1997; 94(9): 4615-4619.

18. Lee HL, Park SH, Kim TM, Jung YY, Park MH, Oh SH, Yun HS, Jun HO, Yoo HS, Han SB, 
Lee US, Yoon JH, Song MJ, Hong JT. Bee venom inhibits growth of human cervical tumors in mice. Oncotarget. 2015; 6(9): 7280-7292.

19. Yang A, Wilson NS, Ashkenazi A. Proapoptotic DR4 and DR5 signaling in cancer cells: toward clinical translation. Curr Opin Cell Biol. 2010; 22(6): 837-844.

20. Allen JE, El-Deiry WS. Regulation of the human TRAIL gene. Cancer Biol Ther. 2012; 13(12): 1143-1151.

21. Sun R, Zhang Y, Lv Q, Liu B, Jin M, Zhang W, He Q, Deng M, Liu X, Li G, Li Y, Zhou G, Xie P, Xie X, Hu J, Duan Z. Toll-like receptor 3 (TLR3) induces apoptosis via death receptors and mitochondria by up-regulating the transactivating $\mathrm{p} 63$ isoform alpha (TAP63alpha). J Biol Chem. 2011; 286(18): 15918-15928.

22. Twomey JD, Kim SR, Zhao L, Bozza WP, Zhang B. Spatial dynamics of TRAIL death receptors in cancer cells. Drug Resist Updat. 2015; 19: 13-21.

23. Holland PM. Death receptor agonist therapies for cancer, which is the right TRAIL? Cytokine Growth Factor Rev. 2014; 25(2): 185-193.

24. Piao X, Ozawa T, Hamana H, Shitaoka K, Jin A, Kishi H, Muraguchi A. TRAIL-receptor 1 IgM antibodies strongly induce apoptosis in human cancer cells in vitro and in vivo. Oncoimmunology. 2016; 5(5): el131380.

25. Kumazaki M, Shinohara H, Taniguchi K, Takai T, Kuranaga Y, Sugito N, Akao Y. Perturbation of the Warburg effect increases the sensitivity of cancer cells to TRAIL-induced cell death. Exp Cell Res. 2016; 347(1): 133-142.

26. Nogueira DR, Yaylim I, Aamir Q, Kahraman OT, Fayyaz S, Kamran-ul-Hassan Naqvi S, Farooqi AA. TRAIL mediated signaling in pancreatic cancer. Asian Pac J Cancer Prev. 2014; 15(15): 5977-5982.

27. Talekar MK, Allen JE, Dicker DT, El-Deiry WS. ONC201 induces cell death in pediatric nonHodgkin's lymphoma cells. Cell Cycle. 2015; 14(15): 2422-2428.

28. Li X, Huang JM, Wang JN, Xiong XK, Yang XF, Zou F. Combination of chrysin and cisplatin promotes the apoptosis of Hep G2 cells by upregulating p53. Chem Biol Interact. 2015; 232: 12-20.

29. Kollipara PS, Jeong HS, Han SB, Hong JT. (E)-2,4-bis(p-hydroxyphenyl)-2-butenal has an antiproliferative effect on NSCLC cells induced by $\mathrm{p} 38$ MAPK-mediated suppression of NF- $\mathrm{BB}$ and up-regulation of TNFRSF10B (DR5). $\mathrm{Br} J$ Pharmacol. 2013; 168(6): 1471-1484.

30. Huet HA, Growney JD, Johnson JA, Li J, Bilic S, Ostrom L, Zafari M, Kowal C, Yang G, Royo A, Jensen M, Dombrecht B, Meerschaert KR, Kolkman JA, Cromie KD, Mosher R, Gao H, Schuller A, Isaacs R, Sellers WR, Ettenberg SA. Multivalent nanobodies targeting death receptor 5 elicit superior tumor cell killing through efficient caspase induction. MAbs. 2014; 6(6): 1560-1570.

31. Kobayashi E, Kishi H, Ozawa T, Hamana H, Nakagawa H, Jin A, Lin Z, Muraguchi A. A chimeric antigen receptor for TRAIL-receptor 1 induces apoptosis in various types of tumor cells. Biochem Biophys Res Commun. 2014; 453(4): 798-803.

32. Zhang M, Su L, Xiao Z, Liu X, Liu X. Methyl jasmonate induces apoptosis and pro-apoptotic autophagy via the ROS pathway in human nonsmall cell lung cancer. Am J Cancer Res. 2016; 6(2): 187-199.

33. Krönung SK, Beyer U, Chiaramonte ML, Dolfini D, Mantovani R, Dobbelstein M. LTR12 promoter activation in a broad range of human tumor cells by HDAC inhibition. Oncotarget. 2016; 7(23): 33484-33497.

34. Beyer U, Krönung SK, Leha A, Walter L, Dobbelstein M. Comprehensive identification of genes driven by ERV9-LTRs reveals TNFRSF10B as a re-activatable mediator of testicular cancer cell death. Cell Death Differ. 2016; 23(1): 64-75.

35. Yu R, Albarenque SM, Cool RH, Quax WJ, Mohr A, Zwacka RM. DR4 specific TRAIL variants are more efficacious than wild-type TRAIL in pancreatic cancer. Cancer Biol Ther. 2014; 15(12): 1658-1666.

36. Khan M, Bi Y, Qazi JI, Fan L, Gao H. Evodiamine sensitizes U87 glioblastoma cells to TRAIL via the death receptor pathway. Mol Med Rep. 2015; 11(1): 257-262.

37. Wang J, Hansen K, Edwards R, Van Houten B, Qian W. Mitochondrial division inhibitor 1 (mdivi-1) enhances death receptor-mediated apoptosis in human ovarian cancer cells. Biochem Biophys Res Commun. 2015; 456(1): 7-12.

38. Tse AC, Li JW, Chan TF, Wu RS, Lai KP. Hypoxia induces miR-210, leading to anti- 
apoptosis in ovarian follicular cells of marine medaka Oryzias melastigma. Aquat Toxicol. 2015; 165: 189-196.

39. Lin CM, Ma JM, Zhang L, Hao ZY, Zhou J, Zhou ZY, Shi HQ, Zhang YF, Shao EM, Liang CZ. Inhibition of Transient Receptor Potential Melastain 7 Enhances Apoptosis Induced by TRAIL in PC-3 cells. Asian Pac $J$ Cancer Prev. 2015; 16(10): 4469-4475.

40. Xu K, Olsen O, Tzvetkova-Robev D, TessierLavigne M, Nikolov DB. The crystal structure of DR6 in complex with the amyloid precursor protein provides insight into death receptor activation. Genes Dev. 2015; 29(8):785-790.

41. Mirzaei MR, Najafi A, Arababadi MK, Asadi MH, Mowla SJ. Altered expression of apoptotic genes in response to OCT4B1 suppression in human tumor cell lines. Tumour Biol. 2014; 35(10): 9999-10009.

42. Jang JY, Jeon YK, Choi Y, Kim CW. Shorthairpin RNA-induced suppression of adenine nucleotide translocase-2 in breast cancer cells restores their susceptibility to TRAIL-induced apoptosis by activating JNK and modulating TRAIL receptor expression. Mol Cancer. 2010; 9: 262.

43. He Y, Yu Z, Ge D, Wang-Sattler R, Thiesen HJ, Xie L, Li Y. Cell type specificity of signaling: view from membrane receptors distribution and their downstream transduction networks. Protein Cell. 2012; 3(9): 701-713.

44. Lalaoui N, Morlé A, Mérino D, Jacquemin G, Iessi E, Morizot A, Shirley S, Robert B, Solary E, Garrido C, Micheau O. TRAIL-R4 promotes tumor growth and resistance to apoptosis in cervical carcinoma HeLa cells through AKT. PLoS One. 2011; 6(5): e19679.

45. Gottwald L, Pasz-Walczak G, Piekarski J, Szwalski J, Kubiak R, Spych M, Suzin J, Tyliński W, Sęk P, Jeziorski A. Membrane expression of trail receptors DcR1 and DcR2 in the normal endometrium, endometrial atypical hyperplasia and endometrioid endometrial cancer. J Obstet Gynaecol. 2014; 34(4): 346-349.

46. Tanenbaum DG, Hall WA, Colbert LE, Bastien AJ, Brat DJ, Kong J, Kim S, Dwivedi B, Kowalski J, Landry JC, Yu DS. TNFRSF10C copy number variation is associated with metastatic colorectal cancer. $J$ Gastrointest Oncol. 2016; 7(3): 306-314.

47. Shin D, Kwon HY, Sohn EJ, Nam MS, Kim JH, Lee JC, Ryu SY, Park B, Kim SH. Upregulation of Death Receptor 5 and Production of Reactive Oxygen Species Mediate Sensitization of PC-3 Prostate Cancer Cells to TRAIL Induced Apoptosis by Vitisin A. Cell Physiol Biochem. 2015; 36(3): 1151-1162.

48. Narayan G, Xie D, Ishdorj G, Scotto L, Mansukhani M, Pothuri B, Wright JD, Kaufmann AM, Schneider A, Arias-Pulido H, Murty VV. Epigenetic inactivation of TRAIL decoy receptors at 8p12-21.3 commonly deleted region confers sensitivity to Apo2L/ trail-Cisplatin combination therapy in cervical cancer. Genes Chromosomes Cancer. 2016; 55(2): 177-189.

49. Ratzinger $\mathrm{G}$, Mitteregger S, Wolf B, Berger R, Zelger B, Weinlich G, Fritsch P, Goebel G, Fiegl H. Association of TNFRSF10D DNAmethylation with the survival of melanoma patients. Int J Mol Sci. 2014; 15(7): 11984-11995.

50. Pei GT, Wu CW, Lin WW. Hypoxia-induced decoy receptor 2 gene expression is regulated via a hypoxia-inducible factor lalpha-mediated mechanism. Biochem Biophys Res Commun. 2010; 391(2): 1274-1279.

51. Mansour NM, Bernal GM, Wu L, Crawley CD, Cahill KE, Voce DJ, Balyasnikova IV, Zhang W, Spretz R, Nunez L, Larsen GF, Weichselbaum RR, Yamini B. Decoy Receptor DcR1 Is Induced in a p50/Bcl3-Dependent Manner and Attenuates the Efficacy of Temozolomide. Cancer Res. 2015; 75(10): 2039-2048.

52. Jiang YQ, Zhong TF, Dang YW, Zou LS, Yang L, Yang X, Chen G. Overexpression and clinicopathological contribution of DcR3 in bladder urothelial carcinoma tissues. Asian Pac J Cancer Prev. 2014; 15(21): 9137-9142.

53. Jiang $M$, Lin $X$, He R, Lin X, Liang L, Tang R, Xiong D, Wei K, Dang Y, Feng Z, Chen G. Decoy Receptor 3 (DcR3) as a Biomarker of Tumor Deterioration in Female Reproductive Cancers: A Meta-Analysis. Med Sci Monit. 2016; 22: $1850-1857$.

54. Im J, Kim K, Hergert P, Nho RS. Idiopathic pulmonary fibrosis fibroblasts become resistant to Fas ligand-dependent apoptosis via the alteration of decoy receptor 3. J Pathol. 2016; 240(1): 25-37.

55. Hu R, Liu W, Qiu X, Lin Z, Xie Y, Hong X, Paerhati R, Qi Z, Zhuang G, Liu Z. Expression of tumor necrosis factor- $\alpha$-induced protein 8 in stage III gastric cancer and the correlation with 
DcR3 and ERK1/2. Oncol Lett. 2016; 11(3): 1835-1840.

56. Zhang Y, Li D, Zhao X, Song S, Zhang L, Zhu D, Wang Z, Chen X, Zhou J. Decoy receptor 3 suppresses FasL-induced apoptosis via ERK1/2 activation in pancreatic cancer cells. Biochem Biophys Res Commun. 2015; 463(4): 1144-1151.

57. Goswami S, Sharma-Walia N. Osteoprotegerin rich tumor microenvironment: implications in breast cancer. Oncotarget. 2016 Apr 8. [Epub ahead of print].

58. Steagall WK, Pacheco-Rodriguez G, Glasgow CG, Ikeda Y, Lin JP, Zheng G, Moss J. Osteoprotegerin contributes to the metastatic potential of cells with a dysfunctional TSC2 tumor-suppressor gene. Am J Pathol. 2013; 183(3): 938-950.

59. Bosman MC, Reis CR, Schuringa JJ, Vellenga E, Quax WJ. Decreased affinity of recombinant human tumor necrosis factor-related apoptosis-inducing ligand (rhTRAIL) D269H/ E195R to osteoprotegerin (OPG) overcomes TRAIL resistance mediated by the bone microenvironment. J Biol Chem. 2014; 289(2): 1071-1078.

60. Huang H, Ma L, Kyrkanides S. Effects of vascular endothelial growth factor on osteoblasts and osteoclasts. Am J Orthod Dentofacial Orthop. 2016; 149(3): 366-373.

61. Chouchana L, Fernández-Ramos AA, Dumont F, Marchetti C, Ceballos-Picot I, Beaune P, Gurwitz D, Loriot MA. Molecular insight into thiopurine resistance: transcriptomic signature in lymphoblastoid cell lines. Genome Med. 2015; 7(1): 37.

62. Bonazzi VF, Nancarrow DJ, Stark MS, Moser RJ, Boyle GM, Aoude LG, Schmidt C, Hayward NK. Cross-platform array screening identifies COL1A2, THBS1, TNFRSF10D and UCHL1 as genes frequently silenced by methylation in melanoma. PLoS One. 2011; 6(10): e26121.

63. Todorova T, Bock FJ, Chang P. PARP13 regulates cellular mRNA post-transcriptionally and functions as a pro-apoptotic factor by destabilizing TRAILR4 transcript. Nat Commun. 2014; 5: 5362.

64. Todorova T, Bock FJ, Chang P. Poly(ADPribose) polymerase-13 and RNA regulation in immunity and cancer. Trends Mol Med. 2015; 21(6): 373-384.
65. Zuo C, Qiu X, Liu N, Yang D, Xia M, Liu J, Wang X, Zhu H, Xie H, Dan H, Li Q, Wu Q, Burns M, Liu C. Interferon- $\alpha$ and cyclooxygenase-2 inhibitor cooperatively mediates TRAILinduced apoptosis in hepatocellular carcinoma. Exp Cell Res. 2015; 333(2): 316-326.

66. Weber TG, Pöschinger T, Galbán $\mathrm{S}$, Rehemtulla A, Scheuer W. Noninvasive monitoring of pharmacodynamics and kinetics of a death receptor 5 antibody and its enhanced apoptosis induction in sequential application with doxorubicin. Neoplasia. 2013; 15(8): 863874.

67. Haselmann V, Kurz A, Bertsch U, Hübner S, Olempska-Müller M1, Fritsch J, Häsler R, Pickl A, Fritsche H, Annewanter F, Engler C, Fleig B, Bernt A, Röder C, Schmidt H, Gelhaus C, Hauser C, Egberts JH, Heneweer C, Rohde AM, Böger C, Knippschild U, Röcken C, Adam D, Walczak H, Schütze S, Janssen O, Wulczyn FG, Wajant H, Kalthoff H, Trauzold A. Nuclear death receptor TRAIL-R2 inhibits maturation of let-7 and promotes proliferation of pancreatic and other tumor cells. Gastroenterology. 2014; 146(1): 278-290.

68. Lim B, Allen JE, Prabhu VV, Talekar MK, Finnberg NK, El-Deiry WS. Targeting TRAIL in the treatment of cancer: new developments. Expert Opin Ther Targets. 2015; 19(9): 11711185.

69. Minchenko OH, Kryvdiuk IV, Minchenko DO, Riabovol OO, Halkin OV. InhibitionofIRE1 signalingaffectsexpression of asubset genes encoding for TNF-related factors andreceptors and modifies their hypoxic regulation in U87 glioma cells. Endoplasm Reticul Stress Dis. 2016; 3(1): 1-15.

70. Tian X, Ye J, Alonso-Basanta M, Hahn SM, Koumenis C, Dorsey JF. Modulation of CCAAT/enhancer binding protein homologous protein (CHOP)-dependent DR5 expression by nelfinavir sensitizes glioblastoma multiforme cells to tumor necrosis factor-related apoptosisinducing ligand (TRAIL). J Biol Chem. 2011; 286(33): 29408-29416.

71. Chevet E, Hetz C, Samali A. Endoplasmic reticulum stress-activated cell reprogramming in oncogenesis. Cancer Discov. 2015; 5(6): 586597. 
72. Wang S, Kaufman RJ. The impact of the unfolded protein response on human disease. J Cell Biol. 2012; 197(7): 857-867.

73. Hetz C, Chevet E, Harding HP. Targeting the unfolded protein response in disease. Nat Rev Drug Discov. 2013; 12(9): 703-719.

74. Manié SN, Lebeau J, Chevet E. Cellular mechanisms of endoplasmic reticulum stress signaling in health and disease. 3. Orchestrating the unfolded protein response in oncogenesis: an update. Am J Physiol Cell Physiol. 2014; 307(10): C901-C907.

75. AufG, Jabouille A, Guérit S, Pineau R, Delugin M, Bouchecareilh M, Magnin N, Favereaux A, Maitre M, Gaiser T, von Deimling A, Czabanka M, Vajkoczy P, Chevet E, Bikfalvi A, Moenner M. Inositol-requiring enzyme lalpha is a key regulator of angiogenesis and invasion in malignant glioma. Proc Natl Acad Sci USA. 2010; 107(35): 15553-15558.

76. Malhotra JD, Kaufman RJ. ER stress and its functional link to mitochondria: role in cell survival and death. Cold Spring Harb Perspect Biol. 2011; 3(9): a004424.

77. Minchenko DO, Kharkova AP, Halkin OV, Karbovskyi LL, Minchenko OH. Effect of hypoxia on the expression of genes encoding insulin-like growth factors and some related proteins in U87 glioma cells without IRE1 function. Endocr Regul. 2016; 50(2): 43-54.

78. Minchenko OH, Tsymbal DO, Minchenko DO, Riabovol OO, Ratushna OO. Hypoxic regulation of the expressions of proliferation related genes in U87 glioma cells upon inhibition of IRE1 signaling. Ukr Biochem J. 2016; 88(1): 11-21.

79. Minchenko OH, Kryvdiuk IV, Riabovol OO, Minchenko DO, Danilovskyi SV, Ratushna OO. Inhibition of IRE1 modifies the hypoxic regulation of GADD family gene expressions in U87 glioma cells. Ukr Biochem J. 2016; 88(2): 25-34.

80. Auf G, Jabouille A, Delugin M, Guérit S, Pineau R, North S, Platonova N, Maitre M, Favereaux A, Vajkoczy P, Seno M, Bikfalvi A, Minchenko D, Minchenko O, Moenner M. High epiregulin expression in human U87 glioma cells relies on IRE1 $\alpha$ and promotes autocrine growth through EGF receptor. BMC Cancer. 2013; 13: 597.

81. Minchenko DO, Danilovskyi SV, Kryvdiuk IV, Bakalets TV, Lypova NM, Karbovsky LL,
Minchenko OH. Inhibition of ERN1 modifies the hypoxic regulation of the expression of TP53related genes in U87 glioma cells. Endoplasm Reticul Stress Dis. 2014; 1(1): 18-26.

82. Minchenko DO, Karbovskyi LL, Danilovskyi SV, Moenner M, Minchenko OH. Effect of hypoxia and glutamine or glucose deprivation on the expression of retinoblastoma and retinoblastomarelated genes in ERN1 knockdown glioma U87 cell line. Am J Mol Biol. 2012; 2(1): 21-31.

83. Minchenko DO, Kharkova AP, Karbovskyi LL, Minchenko $\mathrm{OH}$. Expression of insulin-like growth factor binding protein genes and its hypoxic regulation in U87 glioma cells depends on ERN1 mediated signaling pathway of endoplasmic reticulum stress. Endocr Regul. 2015; 49(2): 73-83.

84. Minchenko OH, Kharkova AP, Minchenko DO, Karbovskyi LL. Effect of hypoxia on the expression of genes that encode some IGFBP and $\mathrm{CCN}$ proteins in U87 glioma cells depends on IRE1 signaling. Ukr Biochem J. 2015; 87(6): 52-63.

85. Zeng L, Li T, Xu DC, Liu J, Mao G, Cui MZ, $\mathrm{Fu} X, \mathrm{Xu} X$. Death receptor 6 induces apoptosis not through type I or type II pathways, but via a unique mitochondria-dependent pathway by interacting with Bax protein. J Biol Chem. 2012; 287(34): 29125-29133.

86. Li T, Su L, Lei Y, Liu X, Zhang Y, Liu X. DDIT3 and KAT2A Proteins Regulate TNFRSF10A and TNFRSF10B Expression in Endoplasmic Reticulum Stress-mediated Apoptosis in Human Lung Cancer Cells. J Biol Chem. 2015; 290(17): 11108-11118.

87. Edagawa M, Kawauchi J, Hirata M, Goshima H, Inoue M, Okamoto T, Murakami A, Maehara Y, Kitajima S. Role of activating transcription factor 3 (ATF3) in endoplasmic reticulum (ER) stress-induced sensitization of p53-deficient human colon cancer cells to tumor necrosis factor (TNF)-related apoptosis-inducing ligand (TRAIL)-mediated apoptosis through up-regulation of death receptor 5 (DR5) by zerumbone and celecoxib. J Biol Chem. 2014; 289(31): 21544-21561.

88. Liu J, Edagawa $M$, Goshima $H$, Inoue $M$, Yagita H, Liu Z, Kitajima S. Role of ATF3 in synergistic cancer cell killing by a combination of HDAC inhibitors and agonistic anti-DR5 antibody through ER stress in human colon 
cancer cells. Biochem Biophys Res Commun. 2014; 445(2): 320-326.

89. Farooqi AA, Li KT, Fayyaz S, Chang YT, Ismail $\mathrm{M}$, Liaw $\mathrm{CC}$, Yuan SS, Tang JY, Chang HW. Anticancer drugs for the modulation of endoplasmic reticulum stress and oxidative stress. Tumour Biol. 2015; 36(8): 5743-5752.

90. Hu R, Du Q, Yin X1, Li J, Wang T, Zhang L. Agonist antibody activates death receptor 6 downstream signaling involving TRADD recruitment. FEBS Lett. 2014; 588(3): 401-407.
91. Johnson GG, White MC, Grimaldi M. Stressed to death: targeting endoplasmic reticulum stress response induced apoptosis in gliomas. Curr Pharm Des. 2011; 17(3): 284-292.

92. Oikonomou E, Pintzas A. The TRAIL of oncogenes to apoptosis. Biofactors. 2013; 39(4): 343-354.

93. Micheau O, Shirley S, Dufour F. Death receptors as targets in cancer. Br J Pharmacol. 2013; 169(8): 1723-1744.

Received 02.09.2016 